Society for the Anthropology of Work • Essential Labor

\title{
Fuzzy Frontiers: Telework and Work-Life Balance in COVID-19 Spain
}

Hugo Valenzuela-Garcia

Published on: Oct 06, 2020

DOI: 10.21428/1d6be30e.962a9633

License: Creative Commons Attribution 4.0 International License (CC-BY 4.0). 
The COVID-19 pandemic has had a dramatic effect on labor markets, forcing a wholesale reorganization of work in some professions. Working from home has become a temporary remedy in some sectors, and this move has recalled enduring aspirations about the structure of work: work without workplaces, work without commuting, and a new relationship between work and life at home. Telework, however, is fraught with contradictions. While it can open new possibilities for work-life balance, it also blurs frontiers in terms of spaces, behaviors, dispositions, and roles. How do people cope with such fuzzy frontiers? And are we witnessing the dawn of a new way of working? Spain, one of the original hotspots for COVID-19 and now in the midst of a second wave, provides some initial insights.

\section{The Advent of Mass Telework in Spain}

Prior to the pandemic, telework was rare in Spain. Apart from the self-employed, a small proportion of Spanish employees (just 4.3 percent) worked from home regularly, compared to 34.7 percent in Sweden or 35.7 percent in the Netherlands. Within less than a month, however, during the nationwide public health alert of early 2020, more than 30 percent of workers were suddenly teleworking. Spain has long resisted a culture of remote work. Most of the major sectors of its economy require physical presence, such as retail, tourism and hospitality, agriculture, and construction. There is also a widespread assumption that productivity is tied to one's physical presence in the workplace.

Although the term telework (teletrabajo, in Spanish) is favored by the press to describe the current situation of remote work, its usage is misleading. Until very recently, this term has been negatively associated with telemarketing and call centers, low-paid industries mainly occupied by migrant women with subpar working conditions (Medel Vicente 2020; Olcese 2020). The new telework is different. The term was adopted almost overnight by 80 percent of Spanish companies, often without adequate planning, infrastructure, or training (Aranda 2020; García 2020; Lafraya 2020). For workers, the consequences were profound; they had little choice but to telework or else face dismissal (El País 2020; Jiménez 2020). Companies experienced the shift differently, too. For larger firms, telework implied a significant reduction of costs. Meanwhile, small or medium-sized firms-the majority in Spain-soon found the costs of spatial restructuring and of finding new ways to organize work to be unsustainable.

\section{The Implications of Telework}

What do Spaniards who are now forced to telework think about their new labor situation? In May 2020, I conducted an online survey in the region of Catalonia to find out.

Of the sixty-four responses to the survey, which followed a snowballing strategy for recruitment and thus cannot be considered representative in a strict sense, most were women (72 percent). All were 
over thirty years old, tending to cluster in the range of forty-one to fifty years of age. Without exception, they were also a highly qualified group: 90.6 percent held a university degree (and 35.9 percent had conducted postgraduate studies as well), while 9.4 percent had completed vocational training.

As for the respondents' home life, 62.5 percent were living with their partners and children, 14.1 percent were single parents, and 17.2 percent lived in a couple without children.

Almost 50 percent of respondents worked in educational and scientific sectors; 22 percent were managers; 11.3 percent IT workers; 7.7 percent healthcare workers; and 6 percent liberal professionals.

Most respondents (92.3 percent) were formally employed, while the remainder were self-employed, business owners, or freelancers. Contrary to reports that the new remote workers had little experience with such arrangements, many of my respondents did have previous experience with telework. Before the lockdown, 28.1 percent worked regularly from home and another 28.1 percent did so frequently, while 43.8 percent rarely or never worked from home.

What did work mean to them? Almost 90 percent of respondents valued their work for reasons beyond their paycheck. Their reasons included: autonomy and self-fulfillment (30.2 percent), practicality, including flexibility and geographic proximity (27 percent), and the work environment (17.5 percent). Surprisingly, wages ranked last in this assessment (14.3 percent). So when we consider the implications of telework for workers, it's clear that we have to think beyond the paycheck. In fact, the implications of telework are manifold and contradictory. On the one hand, working from home saves transportation costs and time (according to 37.5 percent of respondents), allows greater autonomy (34.3 percent), and yields a better balance of work and family life (23.4 percent). On the other, telework expands both workload and the working day, which workers report can lead to selfexploitation (37.5 percent). 


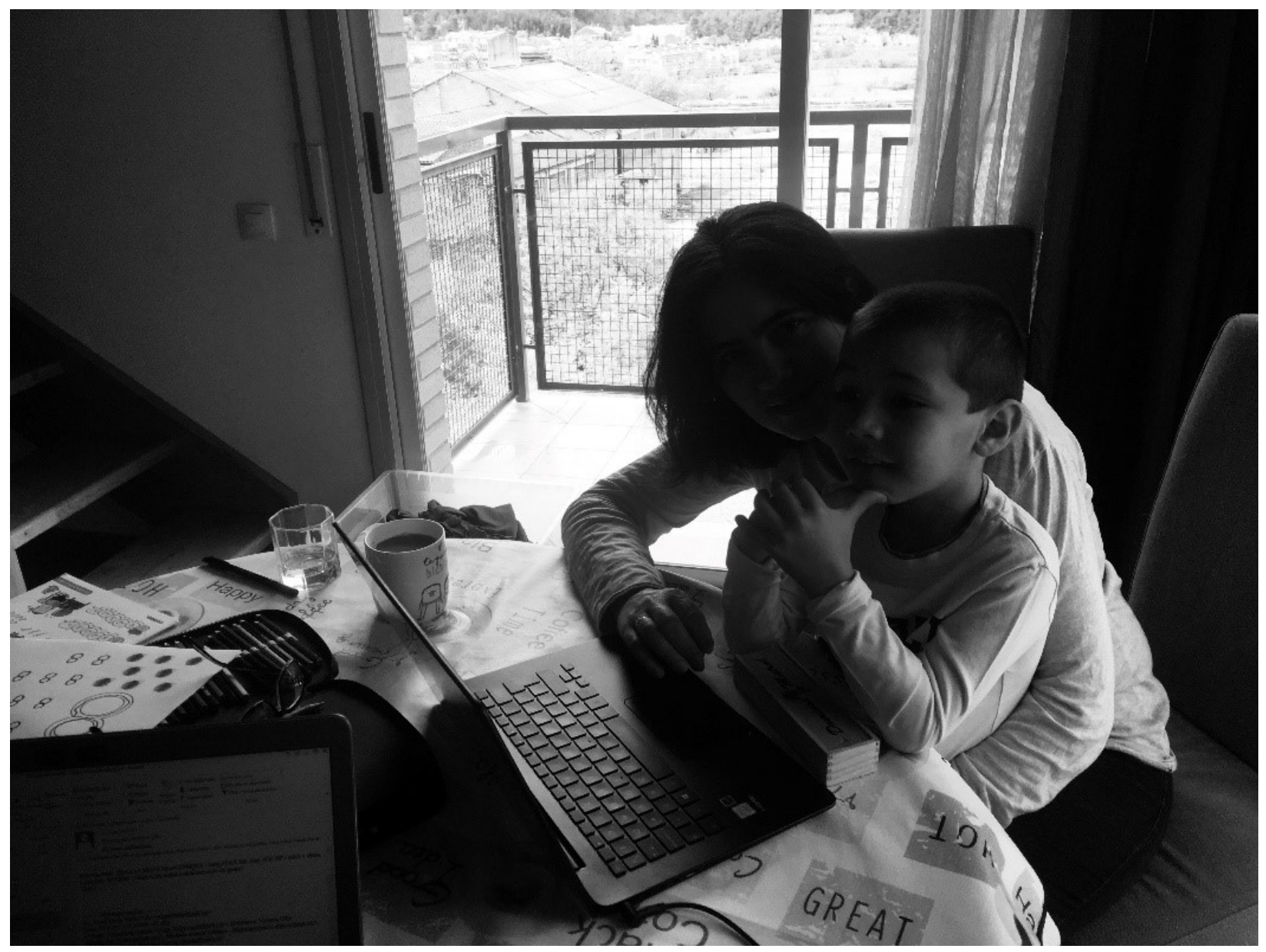

The author's wife and son, on a workday during the lockdown. Photo by Hugo Valenzuela-Garcia.

For some, the new labor conditions are beyond the pale. While in Spain full-time work is calculated at forty hours per week, one teleworker reported that "I work more than twelve hours" per day and added "this is not human." Another suggested that "efficiency dramatically drops, [so] you have to stretch the workday through the morning and night, and that's tiring." Many reported that they missed social relationships at work, and that sociability at work is critical for their well-being. As one teacher wrote:

...human contact is necessary. [Working alone at home] breaks ties and [one] requires more time to do things. Going to work means the time to be me, to be a person, to stop being a mom and to have other social relationships ... GOING TO WORK IS MY TIME, not that of my children and my husband.

But working from home is not only about the absence of a workplace; it is also about the relationship between work space and domestic space. Respondents reported that it is difficult to separate the domestic sphere from that of work, and that doing so involves tremendous stress that affects work and 
home life alike. "At home everything distracts me," wrote one respondent. "I need a formal space. It is alienating to work and live in the same place: you cannot teach from home."

\section{Fuzzy Frontiers}

Not all workers can telework. For those who can, working from home often requires more willpower and discipline than working in a conventional office. It requires a vocational commitment, a high degree of motivation, autonomy, and creativity that has been argued to inhere in what Richard Florida (2002) called the creative class. This type of worker is highly represented in my survey data: teachers, psychologists, health professionals, managers of businesses, IT designers, and so on. But such work entails both a privilege and a risk. On the one hand, these workers do what they love most, an aspirational ideal that in principle should lead to personal fulfillment (Sayer 2011). On the other, as my colleagues and I have written elsewhere, there are costs: "Through self-management employees become their own employers, perhaps the most demanding ones, who self-impose labor control both at home and in their spare time, neglecting their personal and family life. This may result in health problems, substance abuse, mental breakdown" (Valenzuela, Reygadas, and Cruces 2015: 192).

Such problems result from an inability to distinguish the worlds of work and life. Remote work blurs cultural frontiers (see Nipper-Eng 1996), including the temporal structures of the day (home or work?), the social roles that one moves between (spouse, parent, or employee?), one's dispositions toward the activities at hand (relaxed or serious?), and even one's appearance and dress (casual or formal?). When established relationships between these elements of everyday life collapse, respondents to my survey refer to "chaos," "anarchy," and even, metaphorically, "death and destruction." Imbalance happens in both directions: when production overrides reproduction as work takes precedence over domestic tasks like child care, or when family relations, conversely, supplant workplace ones and thus raise questions about job and income security. In either case, working from home can be an incredibly tense experience.

There are a number of factors can either amplify or mitigate those tensions, including how equitably tasks are distributed between domestic partners (García 2020) and what networks for offloading child care and housework, such as kin or hired domestic labor, households can draw upon (Brunat 2020; Lafraya 2020). But restoring a sense of balance within the new world of telework takes work in its own right. This new balance demands that we carve out new distinctions between times and spaces of work, new routines and distributions of domestic and workplace tasks, and even new goals for life at work and home. These are shifts with wide-ranging effects.

\section{Room for Optimism?}

In Spain, telework happened suddenly, but as it becomes a new normal it has allowed us to pose new questions about work, past and present. Respondents to my survey were not, on the whole, 
enthusiastic about remote work. Some 62.5 percent reported that they would prefer to return to their conventional workplace when possible, a finding confirmed by other studies (Brunat 2020). Many hoped for a middle ground between remote and face-to-face work, which would combine the efficiency and mobility of autonomous work, the social components of face-to-face work, and the flexibilities afforded for spending more time with family.

Telework need not be another mode of exploitation, or a further degradation of work and the social life attached to it. Nor should telework be the privilege of the well-paid and well-educated classes. The present shift to telework could be an opportunity to rethink work itself. Although we have already witnessed some of the early effects of this transition-structural changes with respect to leisure, domesticity, and even the physical and economic architectures built on the new industry of teleworknothing is written in stone yet. Telework isn't merely the answer to the current crisis. It's a question of how we can build more emancipatory, sustainable, and encouraging ways of working.

\section{Acknowledgments}

I thank Josh Fisher for his feedback and challenging comments, which contributed to improve this short essay. In addition, I acknowledge the financial support from project number PID2019-111251RBIOO (“Dimensión comunitaria, redes personales y exclusión social [DIMCOM]," Programa Estatal de I+D+i Orientada a los Retos de la Sociedad, del Plan Estatal de Investigación Científica y Técnica y de Innovación 2019-2023).

\section{Author Bio}

Hugo Valenzuela-Garcia is Associate Professor in the Department of Social Anthropology, as well as a member of GRAFO and the Center for Entrepreneurship and Social Innovation Research, at the Universitat Autònoma de Barcelona. As an economic anthropologist, he has carried out fieldwork in Malaysia, Mexico, and Spain, working on fisheries, the peasantry, transnational migrations, ethnic and social entrepreneurship, and consumption. He is currently researching poverty and processes of social exclusion.

\section{Preview Image}

Courtesy of Gilbert Mercier.

\section{References}

Aranda, José Luis. 2020. “Trabajo: Las oficinas tardarán en volver a ser como antes.” El País, May 4.

Brunat, David. 2020. "Padres al borde de un ataque de nervios: queríamos teletrabajo, no esclavitud." El Confidencial, May 15. 
El País. 2020. “Coronavirus: UGTy CC OO piden regular el teletrabajo de los empleados públicos con criterios comunes." Economia, April 28.

Florida, Richard. 2002. The Rise of the Creative Class, and How It's Transforming Work, Leisure, Community, and Everyday Life. New York: Basic Books.

García, Jorge. 2020. “Teletrabajo en tiempos de coronavirus: ¿Deben pagar las empresas los gastos derivados de trabajar desde casa?" Veinte Minutos, April 24.

Jiménez, Francisco. 2020. "La cara oculta del teletrabajo:provocará un aumento de la desigualdad salarial y territorial en España." elEconomista.es, May 12.

Lafraya, Conchi. 2020. "El teletrabajo se impone en las empresas: respuesta rápida para atajar al coronavirus." La Vanguardia, March 14.

Medel Vicente, Aurelio. 2020. “La tentación del teletrabajoy y la pérdida del talento colectivo." Cinco Días, May 1.

Nippert-Eng, Christena. 1996. “Calendar and Keys: The Classification of 'Home' and 'Work."' Sociological Forum 11(3): 563-82.

Olcese, Alejandra. 2020. "Teletrabajar por obligación para cuidar a los hijos condena a los padres a discriminación laboral." Vozpopuli, May 2.

Sayer, Andrew. 2011. Why Things Matter to People: Social Science, Values and Ethical Life. New York: Cambridge University Press.

Valenzuela, Hugo, Luis Reygadas, and Francisco Cruces. 2015. "My.Job is My Life: Overlap between Life and Work in Spanish Companies." Revista Española de Investigaciones Sociológicas 150: 189-208. 